\title{
PENGELOLAAN RISIKO PEMBIAYAAN DI BANK SYARIAH
}

\author{
Trisadini Prasastinah Usanti \\ Fakultas Hukum Universitas Airlangga \\ Email : aditris@ymail.com
}

\begin{abstract}
For Syariah banks, financing is the largest proceeds on one hand, yet-on the other hand-it poses the biggest risk due to its non-performing loans since they prone to not only decrease the banks' total income but also put the banks' CAR (capital adequacy ratio) at risk, which might eventually jeopardize the customers. With respect to this, it is essential that risk management be present in Syariah banks in order to identify, measure, monitor, and control risk level tolerable in their business activities. Embracing this risk management will mitigate risks by putting compatibility to Syariah principles into consideration.
\end{abstract}

Keywords : Risk Management, Financing, Syariah Bank

\begin{abstract}
Abstrak
Pembiayaan adalah sumber pendapatan bank syariah yang terbesar, namun sekaligus merupakan sumber risiko operasi bisnis yang terbesar, yaitu timbulnya Pembiayaan bermasalah, karena dengan adanya pembiayaan bermasalah bukan saja menurunkan pendapatan bagi bank syariah tetapi juga akan berdampak pada kesehatan bank syariah dan pada akhirnya akan merugikan nasabah penyimpan. Oleh karena itu, diperlukan manajemen risiko untuk mengidentifikasi, mengukur, memantau dan mengendalikan risiko yang sesuai dengan kegiatan usaha perbankan syariah. Langkah-langkah tersebut dilakukan dalam rangka memitigasi risiko dengan mempertimbangkan kesesuaian dengan Prinsip Syariah.
\end{abstract}

Kata kunci : Manajemen, Risiko, Pembiayaan, Bank Syariah

\section{PENDAHULUAN}

Sejak diundangkannya Undang-Undang Nomor 7 Tahun 1992 tentang Perbankan ada bentuk alternatif lain disamping bank konvensional yang sudah dikenal masyarakat, yaitu bank yang berdasarkan pada prinsip bagi hasil. UndangUndang Nomor 7 Tahun 1992 tentang Perbankan sama sekali belum menggunakan secara tegas istilah bank syariah. Penyebutannya masih menggunakan istilah " prinsip bagi hasil". Belum ada ketentuan yang lebih rinci mengenai bank yang melakukan kegiatan usaha berdasarkan prinsip syariah. Keberadaan perbankan syariah baru mendapatkan landasan yang kuat sejak 
tanggal 16 Juli 2008 dengan diundangkan Undang-Undang Nomor 21 Tahun 2008 tentang Perbankan Syariah selanjutnya disebut dengan Undang Undang Perbankan Syariah.

Seperti halnya bank konvensional, bank syariah berfungsi juga sebagai lembaga intermediasi (intermediary institution), yaitu berfungsi menghimpun dana dari masyarakat dan menyalurkan kembali dana-dana tersebut kepada masyarakat yang membutuhkannya dalam bentuk pembiayaan. Pembiayaan adalah merupakan sebagian besar aset dari bank syariah sehingga pembiayaan tersebut harus dijaga kualitasnya, sebagaimana diamanatkan pada Pasal 2 Undang-undang Perbankan Syariah bahwa perbankan syariah dalam melakukan kegiatan usahanya berasaskan prinsip syariah, demokrasi ekonomi dan prinsip kehati-hatian. Pada penjelasan Pasal 2 Undang-Undang Perbankan Syariah yang dimaksud dengan prinsip kehati-hatian adalah pedoman pengelolaan Bank yang wajib dianut guna mewujudkan perbankan yang sehat, kuat dan efisien sesuai dengan ketentuan peraturan perundang-undangan. Dari berbagai sumber dapat disimpulkan bahwa yang dimaksud dengan prinsip kehati-hatian adalah pengendalian risiko melalui penerapan peraturan perundang-undangan dan ketentuan yang berlaku secara konsisten. ${ }^{1}$

Prinsip kehati-hatian diatur dalam rambu-rambu kesehatan antara lain diatur pada Pasal 23 dan Pasal 36 Undang-Undang Perbankan Syariah. Pada Pasal 23 (1) Undang-Undang Perbankan syariah mengatur bahwa "Bank syariah dan/atau UUS harus mempunyai keyakinan atas kemauan dan kemampuan calon nasabah Penerima Fasilitas untuk melunasi seluruh kewajiban pada waktunya, sebelum Bank Syariah dan/ atau UUS menyalurkan dana kepada nasabah Penerima Fasilitas". Untuk mendapatkan keyakinan maka bank syariah wajib melakukan penilaian yang seksama terhadap watak, kemampuan, modal, agunan ${ }^{2}$, dan prospek usaha dari calon nasabah penerima fasilitas (character, capacity, capital, collateral, condition). Pada Pasal 36 Undang-Undang Perbankan Syariah

\footnotetext{
${ }^{1}$ Yahman dan Trisadini Prasastinah Usanti, Bunga Rampai Hukum Aktual Dalam Perspektif Hukum Bisnis Kontraktual Berimplikasi Pidana dan Perdata, (Mitra Mandiri: Surabaya,2011), hal.136

${ }^{2}$ Pada Pasal 1.26 Undang-Undang Perbankan Syariah agunan diberikan pengertian sebagai jaminan tambahan, baik berupa benda bergerak maupun tidak bergerak yang diserahkan oleh pemilik agunan kepada Bank syariah dan/atau UUS, guna menjamin pelunasan kewajiban nasabah penerima fasilitas
} 
diatur bahwa "Dalam memberikan pembiayaan dan melakukan kegiatan usaha lainnya, bank syariah dan UUS wajib menempuh cara-cara yang tidak merugikan bank syariah dan UUS dan kepentingan nasabah yang mempercayakan dananya", sehingga bank syariah dalam memberikan pembiayaan wajib mempunyai keyakinan atas kemauan dan kemampuan dari nasabah penerima fasilitas.

Dasar filosofis eksistensi prinsip kehati-hatian pada kegiatan usaha perbankan pada hakikatnya adalah sebagai jaminan kepercayaan masyarakat kepada perbankan, pada perbankan syariah tidak sebatas jaminan kepercayaan tetapi dimaknai sebagai jaminan atas amanah yang sudah diberikan oleh masyarakat. Perbankan syariah tidak semata-mata berfungsi sebagai lembaga intermediasi, tetapi juga berfungsi sosial dan merupakan mitra nasabah. Oleh karena itu, untuk melindungi kepentingan dana masyarakat maka perbankan syariah wajib memegang teguh prinsip kehati-hatian agar perbankan syariah selaku pemegang amanah dalam keadaan sehat, likuid, solvent dan profitable. Hubungan hukum bank syariah dengan nasabah adalah didasarkan pada prinsip amanah. Tidak terbatas pada kepercayaan yang didasarkan pada itikad baik saja tetapi juga kepercayaan yang dilandasi dengan nilai ketauhidan bahwa apa yang dilakukan senantiasa diawasi oleh Allah swt, sehingga setiap tindakan yang dilakukan merupakan ibadah, sehingga tujuan dari perbankan syariah tidak semata-mata mencari keuntungan (profit oriented) tetapi juga mencari kemakmuran di dunia dan kebahagian di akhirat (falah oriented). ${ }^{3}$ Sutan Remy Sjahdeini merumuskan bahwa tujuan dari diberlakukannya prinsip kehati-hatian tidak lain agar bank-bank selalu dalam keadaan sehat, sehingga antara lain selalu dalam keadaan likuid, solvent dan menguntungkan (profitable). Dengan diberlakukannya prinsip kehati-hatian itu diharapkan kadar kepercayaan masyarakat terhadap perbakan selalu tinggi sehingga masyarakat bersedia dan tidak ragu-ragu menyimpan dananya di bank. ${ }^{4}$

Burhanuddin Susanto menekankan bahwa perbankan syariah harus senantiasa menjaga kepercayaan masyarakat baik dari aspek finansial maupun

\footnotetext{
${ }^{3}$ Trisadini Prasastinah Usanti,"Karakteristik Prinsip Kehati-Hatian Pada Kegiatan Usaha Perbankan Syariah”, Disertasi, (Surabaya: Pascasarjana Unair, 2010), hal.311

${ }^{4}$ Sutan Remy Sjahdeini, Kapita Selecta Hukum Perbankan ,Jilid I, tanpa tahun, hal.53
} 
kesesuaian terhadap prinsip syariah yang menjadi dasar operasinya. Perbankan syariah sebagai lembaga yang berfungsi untuk menghimpun dana masyarakat, harus memiliki sumber pendanaan yang optimal sebelum menyalurkan kembali kepada pihak yang membutuhkan. Dalam proses penghimpunan dana, prinsip syariah yang perlu mendapat perhatian lembaga perbankan ialah bagaimana menjamin perolehan dana yang halal, serta bagaimana menjalankan transaksi dengan pihak nasabah secara syar' ${ }^{5}{ }^{5}$

Pada sisi aktiva neraca bank syariah bagian terbesar dana operasional setiap bank syariah disalurkan dalam bentuk pembiayaan. Kenyataan ini menggambarkan bahwa pembiayaan adalah sumber pendapatan bank yang terbesar, namun sekaligus merupakan sumber risiko operasi bisnis yang terbesar. pembiayaan bermasalah bahkan menjadi kategori macet menjadi masalah bagi bank syariah, karena dengan adanya pembiayaan bermasalah bukan saja menurunkan pendapatan bagi bank syariah tetapi juga menggerogoti jumlah dana operasional dan likuiditas keuangan bank syariah, yang akhirnya akan menggoyahkan kesehatan bank syariah dan pada akhirnya akan merugikan nasabah penyimpan/nasabah investor. ${ }^{6}$ Sebagian besar dana yang dipergunakan oleh bank syariah dalam menyalurkan dana dalam bentuk pembiayaan adalah dana nasabah penyimpan/nasabah investor, sehingga dana nasabah penyimpan/nasabah investor wajib mendapat perlindungan hukum. Berdasarkan uraian di atas maka permasalahan yang akan dikaji adalah bagaimana bank syariah mengelola risiko pembiayaan?

\section{PEMBAHASAN}

Batasan tentang pembiayaan diatur pada Pasal 1 angka 25 UndangUndang Perbankan Syariah, bahwa pembiayaan adalah penyediaan dana atau tagihan yang dipersamakan dengan itu berupa :

\footnotetext{
${ }^{5}$ Burhanuddin Susanto, Hukum Perbankan Syariah di Indonesia, (Jogjakarta: UII Press, 2008), hal. 286

${ }^{6} \mathrm{Nasabah}$ penyimpan adalah nasabah yang menempatkan dananya di Bank syariah dan/atau UUS dalam bentuk simpanan berdasarkan akad antara Bank syariah atau UUS dan nasabah yang bersangkutan. Nasabah investor adalah nasabah yang menempatkan dananya di Bank syariah dan/atau UUS dalam bentuk investasi berdasarkan akad antara Bank syariah atau UUS dan nasabah bersangkutan. Lihat Pasal 1 angka 17 dan angka 18 Undang-Undang Perbankan Syariah.
} 
a. Transaksi bagi hasil dalam bentuk Mudharabah dan Musyarakah;

b. Transaksi sewa-menyewa dalam bentuk ijarah atau sewabeli dalam bentuk ijarah muntahiyah bit tamlik;

c. Transaksi jual beli dalam bentuk piutang Murabahah, Salam dan Istishna;

d. Transaksi pinjam meminjam dalam bentuk piutang Qardh; dan

e. Transaksi sewa menyewa jasa dalam bentuk Ijarah untuk transaksi multijasa.

Pembiayaan adalah suatu proses mulai dari analisis kelayakan pembiayaan sampai kepada realisasinya. Namun realisasi pembiayaan bukanlah tahap terakhir dari proses pembiayaan. Setelah realisasi pembiayaan maka bank syariah perlu melakukan pemantauan dan pengawasan pembiayaan, karena dalam jangka waktu pembiayaan tidak mustahil terjadi pembiayaan bermasalah dikarenakan beberapa alasan. Bank syariah harus mampu menganalisis penyebab pembiayaan bermasalah sehingga dapat melakukan upaya untuk melancarkan kembali kualitas pembiayaan tersebut.

Analisa pembiayaan adalah suatu kajian untuk mengetahui kelayakan dari suatu proposal pembiayaan yang diajukan nasabah. Melalui hasil analisis dapat diketahui apakah usaha nasabah tersebut layak (feasible) dalam arti bisnis yang dibiayai diyakini dapat menjadi sumber pengembalian dari pembiayaan yang diberikan, jumlah pembiayaan sesuai kebutuhan baik dari sisi jumlah maupun penggunaannya serta tepat struktur pembiayaannya, sehingga mengamankan risiko dan menguntungkan bagi bank syariah dan nasabah. Dalam menganalisa pembiayaan harus diperhatikan kemauan dan kemampuan nasabah untuk memenuhi kewajibannya serta terpenuhinya aspek ketentuan syariah. Bank syariah dalam menyalurkan pembiayaan wajib menempuh cara-cara yang tidak merugikan bank syariah dan kepentingan nasabah yang mempercayakan dananya. Risiko pembiayaan bermasalah dapat diperkecil dengan jalan salah satunya melakukan analisa pembiayaan. Analisa pembiayaan merupakan tahap preventif yang paling penting dan dilaksanakan dengan profesional dapat berperan 
sebagai saringan pertama dalam usaha bank menangkal bahaya pembiayaan bermasalah. Kelayakan pembiayaan merupakan fokus dan hal yang terpenting di dalam pengambilan keputusan pembiayaan karena sangat menentukan kualitas pembiayaan dan kelancaran pembayaran.

Tahapan yang dilalui pada setiap pembiayaan yang disalurkan kepada nasabah penerima fasilitas oleh bank syariah, yaitu sebagai berikut:

1. Sebelum pemberian pembiayaan diputuskan oleh bank syariah, yaitu tahap bank syariah melakukan analisis atas permohonan pembiayaan calon nasabah penerima fasilitas, tahapan ini disebut tahap analisa pembiayaan.

2. Setelah pembiayaan diputuskan oleh bank syariah, maka dilanjutkan dengan pembuatan perjanjian pembiayaan yang diikuti dengan pengikatan agunan untuk pembiayaan yang diberikan ini. Tahap ini disebut tahap dokumentasi pembiayaan.

3. Setelah perjanjian pembiayaan ditandatangani oleh kedua belah pihak dan dokumentasi pengikatan agunan pembiayaan telah selesai dibuat, maka selama pembiayaan itu digunakan oleh nasabah penerima fasilitas sampai jangka waktu pembiayaan belum berakhir bank syariah melakukan monitoring. Tahap ini disebut tahap pengawasan dan pengamanan pembiayaan.

4. Adakalanya pembiayaan yang telah dinikmati nasabah penerima fasilitas masuk dalam kriteria pembiayaan bermasalah, maka bank syariah berupaya untuk memulihkan kondisi tersebut. Tahapan ini disebut tahapan penyelamatan dan penagihan pembiayaan.

Tahap (1), (2) dan (3) adalah merupakan tahapan preventif atau tahapan pencegahan bagi bank syariah agar pembiayaan tersebut tidak masuk kriteria pembiayaan bermasalah, sedangkan tahap (4) merupakan tahapan represif setelah pembiayaan tersebut menjadi pembiayaan bermasalah. 
Pada bank syariah untuk menilai layak tidaknya usulan pembiayaan pada umumnya digunakan “ filosofis tiga pilar" dan 5 C's principles. Filosofi tiga pilar kelayakan usaha nasabah, yaitu :

1. Kredibilitas manajemen yang meliputi kejujuran, itikad baik key person dari nasabah/character dan kemampuan mengelola usaha key person/capability.

2. Kemampuan membayar kembali (repayment capacity) yang meliputi kemampuan usaha nasabah untuk menghasilkan laba dari produk dan jasa yang dijalankan oleh nasabah dan manajemen arus kas usaha nasabah di masa lalu (historical cash flow) termasuk proyeksi arus cash (projected cash flow) di masa mendatang merupakan ukuran utama kemampuan nasabah dalam membayar kembali pembayaran.

3. Jaminan yang diserahkan dianalisa tentang harga jual kembali agunan, kemudahan menjual agunan dan kelengkapan dan keabsahan dokumen agunan.

Upaya preventif yang dilakukan oleh bank syariah sebelum memberikan pembiayaan kepada nasabah, yaitu dengan melakukan analisa $5 \mathrm{Cs}$, yaitu :8

1. Character: penilaian karakter nasabah adalah untuk mengetahui itikad baik nasabah untuk memenuhi kewajibannya (willingness to pay) dan untuk mengetahui moral, watak maupun sifat-sifat pribadi yang positif dan kooperatif. Karakter merupakan faktor yang dominan dan penting sebab walaupun calon nasabah tersebut cukup mampu untuk menyelesaikan utangnya tetapi kalau tidak mempunyai itikad baik tentu akan membawa berbagai kesulitan bagi bank di kemudian hari. Gambaran tentang karakter calon nasabah dapat diperoleh dengan upaya antara lain :

a. Meneliti riwayat hidup calon nasabah;

b. Verifikasi data dengan melakukan interview;

c. Meneliti reputasi calon nasabah tersebut di lingkungan usahanya;

d. Bank Indonesia checking dan meminta informasi antar bank;

\footnotetext{
${ }^{7}$ Trisadini Prasastinah Usanti, Op.cit., hal. 244

${ }^{8}$ Ibid.,hal.245
} 
e. Mencari informasi atau trade checking kepada asosiasi-asosiasi usaha dimana calon nasabah berada;

f. Mencari informasi tentang gaya hidup dan hobi calon nasabah.

2. Capacity, yaitu kemampuan nasabah untuk menjalankan usaha guna memperoleh laba yang diharapkan sehingga dapat mengembalikan pembiayaan diterima, untuk mengukur capacity dilakukan melalui berbagai pendekatan, yaitu :

a. Pendekatan historis yaitu menilai past performance apakah menunjukkan perkembangan dari waktu ke waktu (minimal 2 tahun terakhir).

b. Pendekatan profesi, yaitu menilai latar belakang pendidikan para pengurus. Hal ini sangat penting untuk perusahaan-perusahaan yang menghendaki keahlian teknologi tinggi atau perusahaan yang melakukan profesionalisme tinggi.

c. Pendekatan yuridis, yaitu secara yuridis apakah calon nasabah mempunyai kapasitas untuk mewakili badan usaha yang diwakilinya untuk mengadakan perjanjian pembiayaan dengan bank.

d. Pendekatan manajerial, yaitu menilai kemampuan dan ketrampilan nasabah melaksanakan fungsi-fungsi manajemen dalam memimpin perusahaan.

e. Pendekatan teknis, yaitu menilai kemampuan mengelola faktor-faktor produksi seperti tenaga kerja, sumber bahan baku, peralatan/mesinmesin, administrasi keuangan, industry relation sampai kemampuan merebut pasar.

3. Capital adalah menilai jumlah modal sendiri yang diinvestasikan oleh nasabah dalam usahanya termasuk kemampuan untuk menambah modal apabila diperlukan sejalan dengan perkembangan usahanya.

4. Condition, yaitu kondisi usaha nasabah yang dipengaruhi oleh situasi sosial dan ekonomi. Kondisi dipengaruhi antara lain peraturan-peraturan pemerintah, situasi, politik dan perekonomian dunia, kondisi ekonomi yang mempengaruhi pemasaran, produk dan keuangan. 
5. Collateral, yaitu aset atau benda yang diserahkan nasabah sebagai agunan terhadap pembiayaan yang diterimanya. Collateral tersebut harus dinilai oleh bank untuk mengetahui risiko kewajiban finansial nasabah kepada bank. Penilaian terhadap jaminan meliputi jenis, lokasi, bukti kepemilikan dan status hukumnya. Penilaian terhadap collateral dapat ditinjau dari dua segi sebagai berikut :

a. Segi ekonomis, yaitu nilai ekonomis dari benda yang akan diagunkan.

b. Segi yuridis, yaitu menilai apakah agunan tersebut memenuhi syaratsyarat yuridis untuk dipakai sebagai agunan.

Prinsip $5 \mathrm{C}$ tersebut kadang ditambahkan dengan $1 \mathrm{C}$ lainnya, yaitu constraint atau hambatan-hambatan yang mungkin menggangu proses usaha. ${ }^{9}$

Salah satu unsur yang penting dari prinsip $5 \mathrm{C}$ adalah adanya collateral. Keberadaaan collateral sangat penting dalam pembiayaan karena dana yang dipergunakan oleh bank syariah dalam rangka penyaluran dana adalah nasabah penyimpan/nasabah investor, sehingga keberadaan collateral adalah untuk menjamin pelunasan pembiayan jika terjadi pembiayaan bermasalah. Bank syariah dalam memberikan pembiayaan wajib menempuh cara-cara yang tidak merugikan bank dan kepentingan nasabahnya yang telah mempercayakan dananya. Selain itu juga adanya keharusan bagi setiap bank syariah untuk terus menjaga kesehatannya dan memelihara amanah masyarakat padanya.

Menurut Muhammad Syafii Antonio bahwa tujuan analisis pembiayaan tersebut, untuk menyakinkan bank bahwa pembiayaan yang dimohonkan itu adalah layak dan dapat dipercaya serta tidak fiktif. Suatu pembiayaan tidak akan disetujui sebelum dipastikan beberapa hal pokok, yaitu : ${ }^{10}$

1. Apakah objek pembiayaan halal atau haram?

2. Apakah proyek menimbulkan kemudharatan untuk masyarakat?

3. Apakah proyek berkaitan dengan perbuatan asusila?

4. Apakah proyek berkaitan dengan perjudian?

\footnotetext{
${ }^{9}$ Ibid

${ }^{10}$ Muhamad Syafi'i Antonio, Bank Syariah : Suatu Pengenalan Umum, (Jakarta: Tazkia Institute, 2000), hal. 33
} 
5. Apakah usaha itu berkaitan dengan industri senjata ilegal atau berorientasi pada pengembangan senjata pembunuh massal?

6. Apakah proyek dapat merugikan syiar Islam, baik secara langsung maupun tidak langsung?

Sedangkan Zainul Arifin, menekankan bahwa perlunya bank syariah berhati-hati pada saat akan memberikan pembiayaan pada usaha nasabah, oleh karenanya bank syariah harus menghidari usaha, yaitu $:^{11}$

1. Usaha yang tidak sesuai dengan prinsip syariah ${ }^{12}$

2. Usaha yang bersifat spekulatif (maisir) dan mengandung ketidak pastian yang tinggi (gharar)

3. Usaha yang tidak mempunyai informasi keuangan yang memadai

4. Bidang usaha yang memerlukan keahlian khusus sedang aparat bank tidak memiliki keahlian atau menguasai bidang usaha tersebut.

5. Pengusaha yang bermasalah.

Demikian halnya yang diatur dalam Buku Pedoman Pembiayaan, salah satu dari bank syariah yang memberikan penetapan larangan pemberian fasilitas pembiayaan, yaitu :

1. Melarang pemberian fasilitas pembiayaan cerukan (talangan) dalam rupiah atau valuta asing

2. Melarang pemberian pembiayaan untuk jual beli saham kepada perorangan atau perusahaan (dalam hal ini termasuk pemberian pembiayaan untuk pembelian saham yang dimaksudkan sebagai penyertaan)

3. Melarang pemberian pembiayaan untuk usaha-usaha jasa yang tidak sesuai dengan aspek syariah

4. Melarang pemberian pembiayaan dan garansi bank untuk keperluan ekspor ataupun impor barang-barang yang dilarang pemerintah atau tidak diperbolehkan / dilarang

\footnotetext{
${ }^{11}$ Zainul Arifin, Dasar-Dasar Manajemen Bank Syariah, (Jakarta: Alvabet, 2002), hal.10

${ }^{12}$ Misalnya usaha di bidang perhotelan, pabrik rokok
} 
a. Melarang pemberian pembiayaan kepada pengembang yang bersifat spekulatif dan atau tanpa rencana penggunaan yang jelas baik secara langsung maupun tidak langsung

b. Melarang pemberian pembiayaan kepada nasabah perorangan atau perusahaan yang nama pengurus / pemilik / pemegang kuasa / penjamin / penanggung jawab tercantum dalam daftar kredit macet/black list.

c. Melarang pemberian pembiayaan kepada nasabah / calon nasabah yang mengandung benturan kepentingan dengan pemrosesan dan / atau komite pembiayaan

d. Melarang pemberian pembiayaan kepada perusahaan baru tidak diizinkan / dilarang, tidak termasuk perusahaan baru / vehicle company yang dibentuk khusus untuk menjalankan projek tertentu yang dimiliki perusahaan induknya. $^{13}$

Menurut Muhammad ada beberapa pendekatan analisis pembiayaan yang dilakukan oleh pengelola bank syariah, yaitu:

1. Pendekatan jaminan, artinya bank dalam memberikan pembiayaan selalu memperhatikan kuantitas dan kualitas jaminan yang dimiliki oleh peminjam.

2. Pendekatan karakter, artinya bank mencermati secara sungguh-sungguh terkait dengan karakter nasabah.

3. Pendekatan kemampuan pelunasan artinya bank menganalisis kemampuan nasabah untuk melunasi jumlah pembiayaan yang diambil.

4. Pendekatan dengan studi kelayakan artinya bank memperhatikan kelayakan usaha yang dijalankan oleh nasabah peminjam.

5. Pendekatan fungsi-fungsi bank artinya bank memperhatikan fungsinya sebagai lembaga intermediari keuangan yaitu mengatur mekanisme dana yang dikumpulkan dengan dana yang disalurkan. ${ }^{14}$

\footnotetext{
${ }^{13}$ Trisadini Prasastinah Usanti,Op.cit., hal. 250

${ }^{14}$ Muhammad, Manajemen Bank Syariah, (Yogjakarta: Unit Penerbit dan Percetakan (UPP) AMP YKPN,2005), hal.260
} 
Demikian juga yang dikemukakan oleh Sutan Remy Sjahdeini bahwa analisa pembiayaan diperlukan agar bank syariah memperoleh keyakinan bahwa pembiayaan yang diberikan dapat dikembalikan oleh nasabah. Pada dasarnya ada 2 (dua) aspek yang dianalisa:

1. Analisa terhadap kemauan membayar disebut analisa kualitatif (willingnes to repay). Aspek yang dianalisa mencakup karakter dan komitmen nasabah

2. Analisa terhadap kemampuan membayar disebut analisa kuantitatif (ability to repay). Pendekatan yang digunakan adalah menentukan kemampuan bayar dan perhitungan kebutuhan modal usaha nasabah adalah dengan pendekatan pendapatan bersih. ${ }^{15}$

Secara umum, pembiayaan yang dilakukan bank syariah hanya diberikan kepada nasabah penerima fasilitas yang telah memiliki usaha berkembang, dalam artian pembiayaan tidak akan diberikan kepada usaha yang baru akan berkembang. Kehati-hatian yang lain bahwa pembiayaan yang diberikan oleh bank syariah harus dituangkan dalam bentuk perjanjian tertulis. Hal ini sebagaimana ditegaskan dalam Undang-Undang Nomor 7 Tahun 1992 tentang Perbankan sebagaimana telah diubah dengan Undang-Undang Nomor 10 Tahun 1998, yaitu pada Pasal 8 ayat 2 dan Penjelasannya, yang dirumuskan sebagai berikut: "Bank Umum wajib memiliki dan menerapkan pedoman perkreditan dan pembiayaan berdasarkan Prinsip Syariah, sesuai dengan ketentuan yang ditetapkan oleh Bank Indonesia”, dan penjelasannya, sebagaimana dirumuskan sebagai berikut: "Pokok-pokok ketentuan yang ditetapkan oleh Bank Indonesia memuat antara lain: a. Pemberian kredit atau pembiayaan berdasarkan prinsip syariah dibuat dalam bentuk perjanjian tertulis....". Mengacu pada penjelasan Pasal 8 ayat 2 Undang Undang Perbankan tersebut, maka dalam praktik perbankan syariah pemberian pembiayaan wajib dituangkan dalam perjanjian pembiayaan secara tertulis, karena terkait dengan fungsinya sebagai alat bukti bagi para pihak yang membuatnya.

\footnotetext{
${ }^{15}$ Sutan Remy Sjahdeini, Op.Cit.,hal.175
} 
Pembiayaan yang telah disetujui oleh bank syariah dan dinikmati oleh nasabah penerima fasilitas, maka peranan bank syariah lebih berat dibandingkan pada saat dana tersebut belum mengucur di tangan nasabah penerima fasilitas. Untuk menghindari terjadinya kegagalan pembiayaan maka bank syariah harus melakukan pembinaan dan regular monitoring, yaitu dengan cara monitoring aktif dan monitoring pasif. Monitoring aktif, yaitu mengunjungi nasabah secara regular, memantau laporan keuangan secara rutin dan memberikan laporan kunjungan nasabah/call report kepada komite pembiayaan/supervisor sedangkan monitoring pasif, yaitu memonitoring pembayaran kewajiban nasabah kepada bank syariah setiap akhir bulan. Bersamaan pula diberikan pembinaaan dengan memberikan saran, informasi maupun pembinaan tehnis yang bertujuan untuk menghindari kegagalan pembiayaan.

Pada Pasal 38 Undang-Undang Perbankan Syariah diatur bahwa bank syariah dan UUS wajib menerapkan manajemen risiko, prinsip mengenal nasabah dan perlindungan nasabah. Pada penjelasannya diberikan pengertian dari manajemen risiko adalah serangkaian prosedur dan metodologi yang digunakan oleh perbankan untuk mengidentifikasi, mengukur, memantau, dan mengendalikan risiko yang timbul dari kegiatan usaha bank. Peraturan pelaksananya diatur dalam Peraturan Bank Indonesia Nomor 13/23/PBI/2011 tentang Penerapan Manajemen Risiko Bagi Bank Umum Syariah dan Unit Usaha Syariah, dijelaskan bahwa bahwa kegiatan usaha perbankan syariah tidak terlepas dari risiko yang dapat mengganggu kelangsungan bank dikarenakan produk dan jasa perbankan syariah mempunyai karakteristik yang khas sehingga diperlukan manajemen risiko untuk mengidentifikasi, mengukur, memantau dan mengendalian risiko yang sesuai dengan kegiatan usaha perbankan syariah. Langkah-langkah yang dilakukan bank syariah tersebut dalam rangka memitigasi risiko harus mempertimbangkan kesesuaian dengan Prinsip Syariah.

Menurut Zainul Arifin bahwa manajemen merupakan suatu metode pengelolaan yang baik dan benar, untuk menghindari kesalahan, kekeliruan dan menegakkan kebenaran. Menegakkan kebenaran adalah metode Allah yang harus ditaati oleh manusia. Dengan demikian manajemen yang disusun oleh manusia 
untuk menegakkan kebenaran itu menjadi wajib. ${ }^{16}$ Manajemen dalam Islam bersandar pada ijtihad pemimpin dan umatnya, dengan catatan tidak boleh bertentangan dengan konsep dasar dan prinsip hukum yang bersumber dari Al Quran dan hadits. Rasulullah saw bersabda dalam sebuah hadits yang diriwayatkan oleh Ath-Thabrani : ${ }^{17}$

"Sesungguhnya Allah sangat mencintai orang yang jika melakukan sesuatu pekerjaan, dilakukan secara itqan (tepat, terarah, jelas dan tuntas) “ HR.Ath-Thabarani. "Apabila suatu urusan diserahkan pada bukan ahlinya, maka tunggu saat kehancurannya”. ( H.R. Bukhari)

Bank syariah sebagai lembaga keuangan syariah dalam kegiatan usahanya disatu sisi berusaha mencari keuntungan tetapi disisi lain harus memperhatikan adanya kemungkinan risiko yang timbul dalam kegiatannya. Secara spesifik risiko-risiko yang dihadapi oleh bank syariah meliputi risiko likuiditas, risiko $\operatorname{kredit}^{18}$ (pembiayaan), risiko operasional, risiko hukum, risiko reputasi, risiko startejik, risiko kepatuhan, risiko imbal jasa, risiko investasi, sedangkan risiko bunga bank syariah tidak menghadapinya sebagaimana yang dihadapi oleh bank konvensional.

Risiko yang dihadapi oleh bank syariah lebih kompleks dibandingkan dengan risiko yang dihadapi oleh bank konvensional, Muhammad Ayub mengidentifikasi risiko tambahan yang dihadapi oleh bank syariah, yaitu risiko aset, risiko pasar dan kesesuaian dengan syariah, risiko tingkat pengembalian yang lebih tinggi, risiko gadaian yang lebih besar, risiko legal yang lebih besar dan risiko penarikan yang lebih besar pula. Oleh karena itu, bank berkewajiban melakukan evaluasi yang lebih berhati-hati atas semua risiko yang ada. ${ }^{19}$

Pada Pasal 1 angka 7 PBI Nomor13/23/PBI/2011 tentang Penerapan Manajemen Risiko Bagi Bank Umum Syariah dan Unit Usaha Syariah, yang

\footnotetext{
${ }^{16}$ Zainul Arifin, Op.Cit.,hal.99

${ }^{17}$ Mohamad Hidayat, An Introduction to The Sharia economic, (Jakarta: Zikrul Hakim, 2010), hal.275

${ }^{18}$ Pada Pasal 1 angka 7 PBI Nomor13/23/PBI/2011 tentang Penerapan Manajemen Risiko Bagi Bank Umum Syariah dan Unit Usaha Syariah disebut dengan risiko kredit, yang seharusnya istilah yang dipergunakan konsisten dengan istilah yang dipergunakan pada Pasal 1 angka 25 Undang-Undang Perbankan Syariah, yaitu pembiayaan.

${ }^{19}$ Muhammad Ayub, Understanding Islamic Finance, (England: John Wiley and Sons Ltd, England, 2008), diterjemahkan oleh Aditya Wisnu Pribadi, (Jakarta: Gramedia Pustaka Utama, 2009), hal.131
} 
dimaksud dengan risiko kredit adalah Risiko Kredit adalah Risiko akibat kegagalan nasabah atau pihak lain dalam memenuhi kewajiban kepada Bank sesuai dengan perjanjian yang disepakati. Risiko pembiayaan yang dihadapi oleh bank syariah, yaitu risiko yang timbulnya kerugian diakibatkan kegagalan/ketidakmampuan nasabah dalam memenuhi kewajiban sesuai akad atau perjanjian yang telah ditetapkan antara bank syariah dan nasabah. Risiko pembiayaan umumnya bersumber dari karakter nasabah, kemampuan nasabah dan siklus bisnis. Risiko tersebut dapat berdampak lebih besar bagi bank syariah, sehingga risiko pembiayaan harus diidentifikasi, diukur, dipantau, dan dikendalikan.

Menurut Adiwarman Karim $^{\mathbf{2 0}}$ sasaran kebijakan manajemen risiko adalah mengidentifikasi, mengukur, memantau dan mengendalikan jalannya kegiatan usaha bank dengan tingkat risiko yang wajar secara terarah, terintegrasi dan berkesimbungan, sehingga manajemen risiko berfungsi sebagai filter atau pemberi peringatan dini (early warning system) terhadap kegiatan usaha bank. Tujuan manajemen risiko itu sendiri adalah sebagai berikut :

a. Menyediakan informasi tentang risiko kepada regulator.

b. Memastikan bank tidak mengalami kerugian yang bersifat unacceptable.

c. Meminimalisasi kerugian dari berbagai risiko yang bersifat uncontrolled.

d. Mengukur eksposur dan pemusatan risiko.

e. Mengalokasikan modal dan membatasi risiko.

Manajemen risiko dalam bank Islam mempunyai karakter yang berbeda dengan bank konvesional, terutama karena adanya jenis-jenis risiko yang khas melekat yang hanya ada pada bank syariah. Perbedaan mendasar antara bank Islam dan bank konvensional bukan terletak pada bagaimana cara mengukur (how to measure), melainkan pada apa yang dinilai (what to measure). Perbedaan itu terlihat dalam proses manajemen risiko operasional bank Islam yang meliputi

\footnotetext{
${ }^{20}$ Adiwarman Karim, Bank Islam: Analisis Fiqih dan Keuangan, (Jakarta: RajaGrafindo Persada, 2007),
} hal.256 
identifikasi risiko, penilaian risiko, antisipasi risiko dan monitoring risiko. ${ }^{21} \mathrm{Hal}$ ini dikarenakan dari karakteristik dari kegiatan usaha perbankan syariah yang didasarkan pada berbagai macam prinsip dalam penghimpun dana, penyaluran dana dan pemberian jasa. Identifikasi risiko yang dilakukan oleh bank Islam tidak hanya mencakup berbagai risiko yang ada pada bank-bank pada umumnya, tetapi juga meliputi risiko yang khas yang hanya ada pada bank Islam. Hal ini karena keunikan dari bank Islam tersebut, ada enam keunikan yaitu :

1. Proses transaksi pembiayaan. Karakteristik bank Islam dalam proses ini setidaknya terlihat pada tiga aspek, yaitu proses transaksi pembiayaan syariah, proses transaksi bagi hasil dana pihak ketiga dan proses transaksi devisa.

2. Proses manajemen. Keunikan bank Islam dalam proses manajemen terlihat pada sistem dan prosedur operasional akuntansi.

3. Sumber daya manusia. Keunikan bank Islam dalam sumber daya manusia terlihat pada spesifikasi kapabilitas yang tidak hanya mencakup dalam bidang perbankan secara umum tetapi juga meliputi aspek-aspek syariah.

4. Tehnologi, keunikan bank Islam dalam bidang tehnologi terlihat pada Business Requirement Specification (BRS) untuk pembiayaan berbasis bagi hasil dan Business Requirement Specification (BRS) dana pihak ketiga.

5. Lingkungan eksternal, keunikan bank Islam dalam hal ini terlihat pada keberadaan dual regulatory body, yaitu Bank Indonesia dan Dewan Syariah Nasional.

6. Kerusakan, keunikan bank Islam dalam hal misalnya ketika terjadi kerusakan pada obyek ijarah atau Ijarah Muntahiya Bittamlik. ${ }^{22}$

Risiko pembiayaan yang dihadapi oleh bank syariah berkaitan dengan risiko-risiko yang lain, yaitu Risiko Pasar adalah Risiko pada posisi neraca dan rekening administratif akibat perubahan harga pasar, antara lain Risiko berupa perubahan nilai dari aset yang dapat diperdagangkan atau disewakan. Risiko

\footnotetext{
${ }^{21}$ Ibid

${ }^{22}$ Ibid., hal..257
} 
Likuiditas adalah Risiko akibat ketidakmampuan Bank untuk memenuhi kewajiban yang jatuh tempo dari sumber pendanaan arus kas dan/atau aset likuid berkualitas tinggi yang dapat diagunkan, tanpa mengganggu aktivitas dan kondisi keuangan Bank. Risiko Operasional adalah Risiko kerugian yang diakibatkan oleh proses internal yang kurang memadai, kegagalan proses internal, kesalahan manusia, kegagalan system, dan/atau adanya kejadian kejadian eksternal yang mempengaruhi operasional Bank. Risiko Hukum adalah Risiko akibat tuntutan hukum dan/atau kelemahan aspek yuridis. Risiko Reputasi adalah Risiko akibat menurunnya tingkat kepercayaan stakeholder yang bersumber dari persepsi negatif terhadap Bank. Risiko Stratejik adalah Risiko akibat ketidaktepatan dalam pengambilan dan/atau pelaksanaan suatu keputusan stratejik serta kegagalan dalam mengantisipasi perubahan lingkungan bisnis. Risiko Kepatuhan adalah Risiko akibat Bank tidak mematuhi dan/atau tidak melaksanakan peraturan perundang-undangan dan ketentuan yang berlaku, serta Prinsip Syariah. Risiko Imbal Hasil $^{23}$ (Rate of Return Risk) adalah Risiko akibat perubahan tingkat imbal hasil yang dibayarkan Bank kepada nasabah, karena terjadi perubahan tingkat imbal hasil yang diterima Bank dari penyaluran dana, yang dapat mempengaruhi perilaku nasabah dana pihak ketiga Bank. Risiko Investasi ${ }^{24}$ (Equity Investment Risk) adalah Risiko akibat Bank ikut menanggung kerugian usaha nasabah yang dibiayai dalam pembiayaan bagi hasil berbasis profit and loss sharing.

Sebagaimana contoh bank syariah berkewajiban untuk mematuhi ketentuan-ketentuan yang ada, baik ketentuan internal maupun eksternal, seperti berikut :

a. Ketentuan giro wajib minimum, batas maksimum pemberian pembiayaan.

b. Ketentuan dalam pemberian pembiayaan.

c. Ketentuan dalam pelaporan kepada Bank Indonesia.

d. Ketentuan perpajakan.

e. Ketentuan dalam akad.

\footnotetext{
${ }^{23}$ Risiko imbal jasa timbul dari transaksi yang berdasarkan prinsip bagi hasil, yaitu mudharabah dan musyarakah yang keuntungannya ditentukan pada nisbah bagi hasil

${ }^{24}$ Risiko ini merupakan risiko yang khas pada bank syariah mengingat salah satu transaksi yang dilakukan oleh bank syariah adalah transaksi berdasakan prinsip bagi hasil, yaitu mudharabah dan musyarakah
} 


\section{f. Fatwa Dewan Syariah Nasional (DSN).}

Apabila bank syariah mengabaikan ketentuan dalam pemberian pembiayaan maka berdampak pada risiko pembiayaan, yaitu timbulnya pembiayaan bermasalah. Demikian halnya jika bank syariah mengabaikan kepatuhan pada fatwa DSN maka akan berdampak pada risiko reputasi (reputation risk) dari bank syariah. Penerapan prinsip syariah dalam kegiatan usaha bank syariah harus dilaksanakan secara konsekuen agar tidak timbul penilaian negatif terhadap penerapan prinsip syariah karena penilaian negatif terhadap penerapan prinsip syariah dapat mengakibatkan timbulnya publikasi negatif sehingga akan menaikkan tingkat risiko reputasi.

Dampak yang ditimbulkan dari risiko operasional yang mencakup risiko reputasi, risiko kepatuhan, risiko strategi, risiko investasi, risiko hukum dan lainlain dapat berupa $:^{25}$

a. Penarikan besar-besaran terhadap dana pihak ketiga.

b. Timbul masalah likuiditas.

c. Ijin dicabut oleh Bank Indonesia.

d. Kebangkrutan.

Bahwa bilamana bank syariah tidak berhati-hati dalam mengelola risikorisiko tersebut, akibatnya akan berdampak pada kesehatan bank syariah, yang pada akhirnya tidak menutup kemungkinan bank syariah akan kesulitan likuditas dan berakibat menurunnya kepercayaan masyarakat sehingga masyarakat akan menarik dananya secara bersamaan, apabila hal ini terjadi maka akan sangat berpengaruh pada eksistensi pada bank syariah. Bank Indonesia akan berupaya untuk menyehatkan kembali bank syariah, akan tetapi jika upaya yang dilakukan tidak berhasil maka upaya terakhir yang dilakukan oleh Bank Indonesia ${ }^{26}$ dengan mencabut ijin usaha bank syariah.

\footnotetext{
${ }^{25}$ Adiwarman Karim, Op.cit..,hal.278

${ }^{26}$ Berdasarkan Pasal 55 Undang-Undang Nomor 21 Tahun 2011 Tentang Otoritas Jasa Keuangan bahwa : (1) Sejak tanggal 31 Desember 2012, fungsi, tugas, dan wewenang pengaturan dan pengawasan kegiatan jasa keuangan di sektor Pasar Modal, Perasuransian, Dana Pensiun, Lembaga Pembiayaan, dan Lembaga Jasa Keuangan Lainnya beralih dari Menteri Keuangan dan Badan Pengawas Pasar Modal dan Lembaga Keuangan ke OJK. (2) Sejak tanggal 31 Desember 2013, fungsi, tugas, dan wewenang pengaturan dan
} 


\section{PENUTUP}

Bank syariah berfungsi sebagai lembaga intermediasi (intermediary institution), yaitu berfungsi menghimpun dana dari masyarakat dan menyalurkan kembali dana-dana tersebut kepada masyarakat yang membutuhkannya dalam bentuk pembiayaan. Pada sisi aktiva neraca bank syariah bagian terbesar dana operasional setiap bank syariah disalurkan dalam bentuk pembiayaan. Kenyataan ini menggambarkan bahwa pembiayaan adalah sumber pendapatan bank yang terbesar, namun sekaligus merupakan sumber risiko operasi bisnis yang terbesar. pembiayaan bermasalah bahkan menjadi kategori macet menjadi masalah bagi bank syariah, karena dengan adanya pembiayaan bermasalah bukan saja menurunkan pendapatan bagi bank syariah tetapi juga menggerogoti jumlah dana operasional dan likuiditas keuangan bank syariah, yang akhirnya akan menggoyahkan kesehatan bank syariah dan pada akhirnya akan merugikan nasabah penyimpan / nasabah investor. Hal ini dikarenakan sebagian besar dana yang dipergunakan oleh bank syariah dalam menyalurkan dana dalam bentuk pembiayaan adalah dana nasabah penyimpan / nasabah investor, sehingga dana nasabah penyimpan / nasabah investor wajib mendapat perlindungan hukum. Oleh karena itu, diperlukan manajemen risiko untuk mengidentifikasi, mengukur, memantau dan mengendalian risiko yang sesuai dengan kegiatan usaha perbankan syariah. Langkah-langkah yang dilakukan bank syariah tersebut dalam rangka memitigasi risiko harus mempertimbangkan kesesuaian dengan Prinsip Syariah.

Kegiatan usaha bank syariah oleh karena senantiasa dihadapkan pada risiko-risiko yang berkaitan erat dengan fungsinya sebagai lembaga intermediasi keuangan dan perkembangan lingkungan eksternal dan internal perbankan syariah yang semakin pesat mengakibatkan risiko kegiatan usaha perbankan syariah semakin kompleks salah satunya, yaitu risiko pembiayaan maka sejogjanya bank

pengawasan kegiatan jasa keuangan di sektor Perbankan beralih dari Bank Indonesia ke OJK. Pada Pasal 1 angka 1 bahwa Otoritas Jasa Keuangan, yang selanjutnya disingkat OJK, adalah lembaga yang independen dan bebas dari campur tangan pihak lain, yang mempunyai fungsi, tugas, dan wewenang pengaturan, pengawasan, pemeriksaan, dan penyidikan sebagaimana dimaksud dalam Undang-Undang ini. Demikian juga berdasarkan Pasal 55 juncto Pasal 69 ayat 1.c pengawasan pada perbankan syariah dengan dikeluarkannya Undang-Undang Nomor 21 Tahun 2011 Tentang Otoritas Jasa Keuangan akan beralih menjadi fungsi, tugas dan wewenang dari OJK. 
syariah dalam menjalankan kegiatan usahnya harus berhati-hati dalam mengelola risiko-risiko tersebut, karena akan berdampak pada kesehatan bank syariah, yang pada akhirnya tidak menutup kemungkinan bank syariah akan kesulitan likuditas dan berakibat menurunnya kepercayaan masyarakat sehingga masyarakat akan menarik dananya secara bersamaan, apabila hal ini terjadi maka akan sangat berpengaruh pada keberadaan bank syariah.

\section{DAFTAR PUSTAKA}

Antonio, Muhamad Syafi'i, Bank Syariah: Suatu Pengenalan Umum, Jakarta: Tazkia Institute, 2000.

Arifin, Zainul, Dasar-Dasar Manajemen Bank Syariah, (Jakarta: Alvabet, 2002.

Ayub, Muhammad, Understanding Islamic Finance, England: John Wiley and Sons Ltd, England, 2008, diterjemahkan oleh Aditya Wisnu Pribadi, Jakarta: Gramedia Pustaka Utama, 2009.

Hidayat, Mohamad, An Introduction to The Sharia economic, Jakarta: Zikrul Hakim, 2010.

Karim, Adiwarman, Bank Islam: Analisis Fiqih dan Keuangan, Jakarta: RajaGrafindo Persada, 2007.

Muhammad, Manajemen Bank Syariah, Yogjakarta: Unit Penerbit dan Percetakan (UPP) AMP YKPN,2005.

Susanto, Burhanuddin, Hukum Perbankan Syariah di Indonesia, Jogjakarta: UII Press, 2008.

Yahman dan Trisadini Prasastinah Usanti, Bunga Rampai Hukum Aktual Dalam Perspektif Hukum Bisnis Kontraktual Berimplikasi Pidana dan Perdata, Mitra Mandiri: Surabaya, 2011.

Sjahdeini, Sutan Remy, Kapita Selecta Hukum Perbankan, Bahan Kuliah Hukum Perbankan, tanpa tahun.

Usanti, Trisadini Prasastinah,'Karakteristik Prinsip Kehati-Hatian Pada Kegiatan Usaha Perbankan Syariah”, Disertasi, Surabaya: Pascasarjana Unair, 2010. 
428 ADIL : Jurnal Hukum Vol. 3 No.2

Undang-Undang Republik Indonesia Nomor 7 Tahun 1992 Tentang Perbankan Lembaran Negara Republik Indonesia Tahun 1992 Nomor 31, Lembaran Negara Tahun 1992 Nomor 31. Tambahan Lembaran Negara Nomor 3472.

Undang-Undang Republik Indonesia Nomor 10 Tahun 1998 Tentang Perubahan Undang-Undang Nomor 7 Tahun 1992 Tentang Perbankan, Lembaran Negara Republik Indonesia Tahun 1998 Nomor 182. Tambahan Lembaran Negara Nomor 3790.

Undang-Undang Republik Indonesia Nomor 21 Tahun 2008 Tentang Perbankan Syariah, Lembaran Negara Republik Indonesia Tahun 2008 Nomor 94.

Undang-Undang Nomor 21 Tahun 2011 Tentang Otoritas Jasa Keuangan, Lembaran Negara Republik Indonesia Tahun 2011 Nomor 111.

Peraturan Bank Indonesia Nomor13/23/PBI/2011 tentang Penerapan Manajemen Risiko Bagi Bank Umum Syariah dan Unit Usaha Syariah. 